\title{
Microbiological characterization of vegetables and their rhizosphere soil in Eastern Poland
}

\author{
Teresa Kłapeć', Alicja Cholewa', Grażyna Cholewa', Jacek Dutkiewicz'1, Angelina Wójcik-Fatla' \\ ${ }^{1}$ Department of Biological Health Hazards and Parasitology, Institute of Rural Health, Lublin, Poland
}

Kłapeć T, Cholewa A, Cholewa G, Dutkiewicz J, Wójcik-Fatla A. Microbiological characterization of vegetables and their rhizosphere soil in Eastern Poland. Ann Agric Environ Med. 2016; 23(4): 559-565. doi: 10.5604/12321966.1226846

\begin{abstract}
The aim of this study was to investigate the bacteriological quality of 5 kinds of vegetables (lettuce, dill, radish, beetroot, carrot) and their rhizosphere soil, originating from conventional farms located in the Lublin Province of Eastern Poland. A total number of 35 samples of fresh vegetables (FV) taken immediately from soil, 35 samples of soil from rhizosphere of these vegetables (SR) and 35 samples of vegetables sold at retail in the markets in Lublin (VR) were examined. The samples were analysed for the content of: aerobic mesophilic bacteria (AMB) grown at $30^{\circ} \mathrm{C}$ and $37^{\circ} \mathrm{C}$, Gram-negative bacteria of Enterobacteriaceae family, faecal coliform (FC) bacteria, Salmonella spp., and Clostridium perfringens. Median AMB values determined at $30^{\circ} \mathrm{C}$ for FV, SR and VR were 5.27, 5.00, and $5.00 \log _{10} \mathrm{CFU} \mathrm{g}^{-1}$, respectively, being significantly greater compared to those recorded at $37^{\circ} \mathrm{C}$. The exceeding of the threshold value of $6.0 \log _{10} \mathrm{CFU} \mathrm{g}{ }^{-1}$ proposed by Gelosa (1998) was noted only in $5 \mathrm{FV}$ samples grown at $30^{\circ} \mathrm{C}(14.3 \%)$, and in $3 \mathrm{FV}$ samples grown at $37^{\circ} \mathrm{C}(8.6 \%)$. The threshold value was never exceeded in SR and VR samples. Median concentrations of Enterobacteriaceae determined for FV, SR and VR were 4.03, 3.87, and $3.04 \log _{10}$ CFU g ${ }^{-1}$, respectively. Eleven species of Enterobacteriaceae were identified in the FV, SR and VR samples. The percent of samples containing Escherichia coli was greatest for VR (22.9\%), smaller for FV (17.1\%) and smallest for SR (5.7\%). The median concentrations of the faecal coliform bacteria (FC), determined by culture at $44^{\circ} \mathrm{C}$, were low, amounting to $1.000 \log _{10} \mathrm{CFU} \mathrm{g}^{-1}$ for FV and SR and 0.00 for VR. All examined vegetable and soil samples tested negative for the presence of Salmonella. The median concentrations of Clostridium perfringens were low, amounting to $0.00 \log _{10} \mathrm{CFU} \mathrm{g}^{-1}$ for all categories of samples. This bacterium was relatively common in soil samples with the prevalence of $40.0 \%$, but very rare in vegetable samples (occurring in $5.7 \%$ of FV and in none of VR samples). In conclusion, the results of the present study generally indicate that the microbiological quality of Polish vegetables grown on conventional farms is satisfactory and safe for consumers.
\end{abstract}

\section{Key words}

Microbiological quality, vegetables, soil, aerobic bacteria, Enterobacteriaceae, coliform bacteria, Salmonella, Clostridium perfringens

\section{INTRODUCTION}

Fresh fruits and vegetables are increasingly more in demand by consumers. Fruits and vegetables are the only group of products which, without doubt, exert a beneficial effect on the state of health. Vegetables contain all the vitamins, mineral components, as well as fibre and polyphenols, which show pro-health properties similar to vitamins. They contain less simple sugars than fruit and therefore do not increase the risk of obesity.

Many studies show that, unfortunately, raw vegetables, especially the leafy kind, are considerably contaminated microbiologically $[1,2,3,4,5]$. This may create a health risk for consumers due to the possibility of occurrence of pathogenic microflora. The routine procedure for assessment of the microbiological contamination of vegetables includes determination of the levels of total mesophilic aerobic bacteria and Gram-negative bacteria of Enterobacteriaceae family, with special relevance to faecal coliform bacteria as general indicators of pollution $[1,2,4,6,7,8]$. In addition, many authors have determined the presence of bacteria and viruses known as causative agents of gastrointestinal diseases associated with vegetable consumption: Salmonella

Address for correspondence: Dr Teresa Kłapeć, Department of Biological Health Hazards and Parasitology, Institute of Rural Health, Jaczewskiego 2, 20-090 Lublin, Poland

E-mail: teresaklapec@op.pl

Received: 20 September 2016; accepted: 09 November 2016 spp., Escherichia coli O157:H7, Listeria monocytogenes, Campylobacter spp., Yersinia enterocolitica, Clostridium perfringens, Norovirus (NoV), and hepatitis A virus (HAV) $[2,4,9,10,11,12,13]$.

Pathogens contaminating vegetables may be naturally present in soil, e.g. Listeria spp. and $\mathrm{Cl}$. perfringens, or may be introduced with organic fertilizers (Salmonella, E. coli). Pathogens may colonize the plants during cultivation (from soil) or during harvesting, processing and transport. The ability of pathogens to survive in the soil environment depends on the type of pathogen, type of soil, ambient temperature, level of humidity, as well as high resistance of some bacteria to the external conditions.

Literature reports indicate that the bacteria E. coli and Salmonella, due to a high resistance to unfavourable external conditions, may survive for a very long time in the soil environment and in vegetables [14, 15, 16, 17, 18, 19]. Studies by Stroczyńska-Sikorska et al. [20] concerning the survival of some pathogens in experimentally contaminated soil showed that $S$. enteritidis survives in loamy sand during the summer season for 74 days, while in loess soil, during the autumnwinter season - for 186 days. In turn, E. coli bacteria in the same conditions survived for 24 and 81 days, respectively.

The objective of this study was to assess bacteriological contaminations on 5 types of fresh vegetables from conventional farms and markets located in the Lublin Province of Eastern Poland. The numbers of the tested groups of microorganisms in the rhizosphers of these vegetables were also assessed. 


\section{MATERIALS AND METHOD}

Collection of samples. In 2015, from May to September, bacteriological studies were carried out on 5 types of fresh vegetables (FV) from 4 conventional farms located in nearby villages in the Lublin Province, and on soil samples collected from the rhizosphere of these vegetables (SR). In addition, vegetables sold at retail (VR) at market places in Lublin were investigated, which also come from conventional farms. The samples of lettuce (Lactuca sativa), dill (Anethum graveolens), and radish (Raphanus sativus) were collected during the spring season, while the samples of red beetroot (Beta vulgaris) and carrot (Daucus carota) during the autumn season.

A total number of 70 samples of vegetables and 35 samples of soil collected under vegetables were examined. On conventional farms, the investigations included 35 samples of vegetables (red beetroot and carrot - 10 samples each, lettuce, dill and radish -5 samples each), and 35 soil samples. On the markets, 35 samples of vegetables were collected (10 samples of red beetroot and carrot each, and 5 samples of lettuce, dill and radish each).

Preparation of vegetables. Adhering soil was shaken off the roots of radish, carrot, and red beetroot, which were cut into smaller pieces using a sterile knife. Leaves of lettuce and stems of dill were also cut into smaller fragments. 20-gram samples of vegetables were designed for homogenization with $180 \mathrm{ml}$ of solvent (Ringer's solution). From the homogenate prepared in this way, tests for determination of the presence and numbers of total aerobic mesophilic bacteria, total Gram-negative bacteria, bacteria of the faecal coli group, the Salmonella bacteria and Cl. perfringens bacteria, were performed according to the Polish Standards, as described below.

In order to determine the numbers of the above-mentioned bacteria, the method of inoculation of 10 -fold dilutions on differential and selective media was applied. The number of microorganisms was expressed as the number of colonyforming units (CFU) in $1 \mathrm{~g}$ of suspension of homogenized plant material.

Preparation of soil. Soil was crushed, mixed and sieved by passing through a sieve with $2 \mathrm{~mm}$ openings. For bacteriological examinations, 10 -gram samples were designed. The same groups of bacteria were determined and the same methods were applied as in the case of vegetables.

Bacteriological analyses. Included determination of the following:

- total number of aerobic mesophilic bacteria - by culturing on nutrient agar (Biomed) at temperatures of $37^{\circ} \mathrm{C}$ and $30^{\circ} \mathrm{C}$, according to the Polish Standard PN-EN ISO 6222:2004 [21];

- total number of the Gram-negative bacteria of Enterobacteriaceae family - by culture on EMB (Eosin Methylene Blue) Agar (Merck), at the temperature of $37^{\circ} \mathrm{C}$;

- faecal coliform bacteria - by the fermentation tube method on yellow and brilliant green agar, at the temperature of $44^{\circ} \mathrm{C}(24-48 \mathrm{~h})$, according to the Polish Standard PN77/C-04615/07 [22];

- Salmonella bacteria - by culture on proliferation medium with sodium selenate (SF), according to the Polish Standard PN-Z-19000-1/2001 [23], and additionally on the differential and selective medium Rambach Agar.
- spore-forming bacteria - Clostridium perfringens - by culture on Wilson-Blair agar for anaerobic bacteria, according to the Polish Standards PN-74/C-14615/2012 [24].

The above-mentioned bacteria are recognized markers of the degree of contamination of soil, water, waste water, and sewage sludge, and their presence and/or high numbers indicate the unsatisfactory quality of the material examined.

The strains of Gram-negative bacteria isolated from the vegetables and soil on EMB medium were identified to the species level by the biochemical test ENTEROtest $24 \mathrm{~N}$ (Erba Lachema, Brno, Czech Republic), designed for identification of bacteria from the families Enterobacteriaceae and Vibrionaceae.

Statistical analysis. The results were analyzed by MannWhitney and Spearman non-parametric tests, using STATISTICA v. 5.1 package (Statsoft, Tulsa, OK, USA).

\section{RESULTS}

Aerobic mesophilic bacteria (AMB). The median concentrations of AMB isolated from all examined vegetables at $30^{\circ} \mathrm{C}$ were significantly greater compared to concentrations of AMB isolated at $37^{\circ} \mathrm{C}$, accounting for 5.27 vs. $4.64 \log _{10}$ $\mathrm{CFU} \mathrm{g}^{-1}(\mathrm{P}=0.019)$ for fresh vegetables (FV), 5.00 vs. $4.15 \log _{10}$ $\mathrm{CFU} \mathrm{g}{ }^{-1}(\mathrm{P}=0.002)$ for soil from the rhizosphere of vegetables (SR), and 5.00 vs. $4.02 \log _{10} \mathrm{CFU} \mathrm{g}^{-1}(\mathrm{P}<0.00001)$ for vegetables sold at retail (VR) in the market (Tab. 1).

Median values determined for particular kinds of vegetables at $30^{\circ} \mathrm{C}$ and $37^{\circ} \mathrm{C}$ for FV, SR and VR, ranged between $4.86-$ $5.57,4.30-5.19$ and $2.33-5.28 \log _{10} \mathrm{CFU} \mathrm{g}^{-1}$, respectively, and between 4.14-5.46, 4.06-5.07 and 3.98-4.21 $\log _{10}$ CFU g ${ }^{-1}$, respectively (Tab. 1). The exceeding of the threshold value of $6.0 \log _{10}$ CFU g-1 proposed by Gelosa (1998), quoted by De Giusti et al. [11], was noted only in $5 \mathrm{FV}$ samples grown at $30^{\circ} \mathrm{C}(14.3 \%$ of the total examined in this category) and in $3 \mathrm{FV}$ samples grown at $37^{\circ} \mathrm{C}(8.6 \%)$. This threshold value was never exceeded in SR and VR samples.

The concentrations of AMB isolated from total $\mathrm{FV}$ at $30^{\circ} \mathrm{C}$ and $37^{\circ} \mathrm{C}$ were significantly greater compared to $\mathrm{SR}(\mathrm{P}=0.007$ and $\mathrm{P}=0.017$, respectively) and $\mathrm{VR}(\mathrm{P}=0.029$ and $\mathrm{P}=0.00014$, respectively). Similar significant relationships for $\mathrm{FV}$ vs. SR were found for lettuce at $37^{\circ} \mathrm{C}(\mathrm{P}=0.028)$, for dill at $30^{\circ} \mathrm{C}$ $(\mathrm{P}=0.047)$, and for beetroots at $30^{\circ} \mathrm{C}(\mathrm{P}=0.028)$, whereas significant relationships for $\mathrm{FV}$ vs. $\mathrm{VR}$ were found for dill at $30^{\circ} \mathrm{C}(\mathrm{P}=0.029)$ and at $37^{\circ} \mathrm{C}(\mathrm{P}=0.009)$, as well as for radish at $30^{\circ} \mathrm{C}(\mathrm{P}=0.047)$.

When compared the AMB concentrations associated with particular vegetables, it was found that $\mathrm{FV}$ values (at $37^{\circ} \mathrm{C}$ ) of lettuce and dill were significantly greater compared to beetroot ( $\mathrm{P}=0.005$ in both cases) and carrot $(\mathrm{P}=0.007$ and $\mathrm{P}=0.005$, respectively). Similarly, VR values (at $30^{\circ} \mathrm{C}$ and $37^{\circ} \mathrm{C}$ ) of dill were significantly greater compared to beetroots $(\mathrm{P}=0.037$, and $\mathrm{P}=0.049$, respectively). Based on these results, a comparison was made between the concentrations of $\mathrm{AMB}$ in leafy vegetables (lettuce and dill) versus root vegetables (radish, beetroots and carrot). This comparison confirmed a significantly greater content of $\mathrm{AMB}$ in leafy vegetables, both at $30^{\circ} \mathrm{C}$ and $37^{\circ} \mathrm{C}$ for $\mathrm{FV}(\mathrm{P}=0.024$ and $\mathrm{P}=0.0006$, respectively), but not for $\mathrm{VR}$. 
Table 1. Median concentrations and ranges (in parentheses) of aerobic mesophilic bacteria (AMB) in fresh vegetables, in soil from vegetable rhizosphere and in vegetables sold at retail in the market

\begin{tabular}{|c|c|c|c|c|c|c|}
\hline \multirow{3}{*}{$\begin{array}{l}\text { Vegetable } \\
\text { species }\end{array}$} & \multicolumn{6}{|c|}{ Concentration of AMB $\left(\log _{10} \mathrm{CFU} \mathrm{g} \mathrm{g}^{-1}\right)$} \\
\hline & \multicolumn{3}{|c|}{ Bacteria grown at $37^{\circ} \mathrm{C}$ (median, range) } & \multicolumn{3}{|c|}{ Bacteria grown at $30^{\circ} \mathrm{C}$ (median, range) } \\
\hline & Fresh vegetable & Soil & Sold vegetable & Fresh vegetable & Soil & Sold vegetable \\
\hline Lettuce (Lactuca sativa) & $5.15(5.10-6.17)^{5}$ & $4.31(4.26-5.21)$ & $4.01(3.90-4.14)$ & $5.41(4.86-6.32)$ & $5.19(4.92-5.41)$ & $5.07(4.26-5.41)^{\#}$ \\
\hline Dill (Anethum graveolens) & $5.46(5.01-5.59)^{*}$ & $5.07(3.43-5.24)$ & $3.98(2.23-4.07)$ & $5.57(5.27-6.19)^{*}$ & $5.07(4.94-5.32)$ & $4.35(2.23-5.44)$ \\
\hline Radish (Raphanus sativus) & $4.46(4.08-6.22)$ & $5.00(3.43-5.20)$ & $4.00(2.05-5.29)$ & $5.26(4.59-6.29)^{*}$ & $5.17(2.23-5.42)$ & $4.13(2.23-5.42)$ \\
\hline Carrot (Daucus carota) & $4.21(2.91-5.31)$ & $4.06(2.57-4.24)$ & $4.03(2.94-4.56)$ & $4.86(3.54-5.44)$ & $4.52(3.51-5.11)$ & $2.33(0.00-2.60)$ \\
\hline Total samples & $4.64(2.91-6.22)^{5 *}$ & $4.15(2.57-5.24)$ & $4.02(2.05-5.29)$ & $5.27(3.54-6.32)^{\# \$ *}$ & $5.00\left(2.23-5.47^{\#}\right.$ & $5.00(0.00-5.55)^{\#}$ \\
\hline
\end{tabular}

Number of samples analysed in each field equals 5 for lettuce, dill, and radish, 10 for sugar beet and carrot and, 35 for total count.

\# Number significantly greater compared to that grown at $37^{\circ} \mathrm{C}$

$\$$ Number significantly greater compared to soil.

* Number significantly greater compared to sold vegetable.

A highly significant correlation was found between the concentrations of aerobic mesophilic bacteria in fresh vegetables and soil, both for isolates grown at $30^{\circ} \mathrm{C}$ $(\mathrm{P}=0.00016)$ and $37^{\circ} \mathrm{C}(\mathrm{P}=0.00018)$. This seems to support the thesis that most of AMB isolated from fresh vegetables were of soil origin.

Gram-negative bacteria of Enterobacteriaceae family. The median concentrations of Enterobacteriaceae determined for particular kinds of vegetables for FV, SR and VR, ranged between 3.77-5.21, 3.26-4.12 and 2.33-4.16 $\log _{10}$ CFU g-1, respectively (Tab. 2). Similar to AMB, the concentrations of Enterobacteriaceae isolated from all FV were significantly greater compared to $\mathrm{SR}(\mathrm{P}=0.023)$ and VR $(\mathrm{P}=0.0002)$. Conversely to $\mathrm{AMB}$, no difference was found between the concentrations of Enterobacteriaceae in leafy vegetables versus root vegetables for $\mathrm{FV}(\mathrm{P}=0.827)$, but a highly significant difference between these 2 kinds of vegetables was noted for $\operatorname{VR}(\mathrm{P}=0.0006)$.

Eleven species of Enterobacteriaceae were identified in the samples of fresh vegetables (FV), soil (SR) and vegetables sold at retail (VR). The most common were strains of Enterobacter amnigenus found in 20 samples (19.0\% of total samples examined), followed by Escherichia coli - 16 samples (15.2\%), Enterobacter kobei - 15 samples (14.3\%), Tatumella (Pantoea terrea) - 9 samples (8.6\%), Enterobacter cloacae - 7 samples (6.7\%), Enterobacter aerogenes - 5 samples (4.8\%), Raoultella terrigena - 5 samples (4.8\%), Rahnella aquatilis - 2 samples (1.9\%), Hafnia alvei - 1 sample (0.9\%), Serratia plymuthica1 sample (0.9\%), and Vibrio metschnikovii - 1 sample (0.9\%).

Table 2. Median concentrations and ranges (in parentheses) of Gram-negative bacteria of Enterobacteriaceae family in fresh vegetables in soil from vegetable rhizosphere, and in vegetables sold at retail in the market

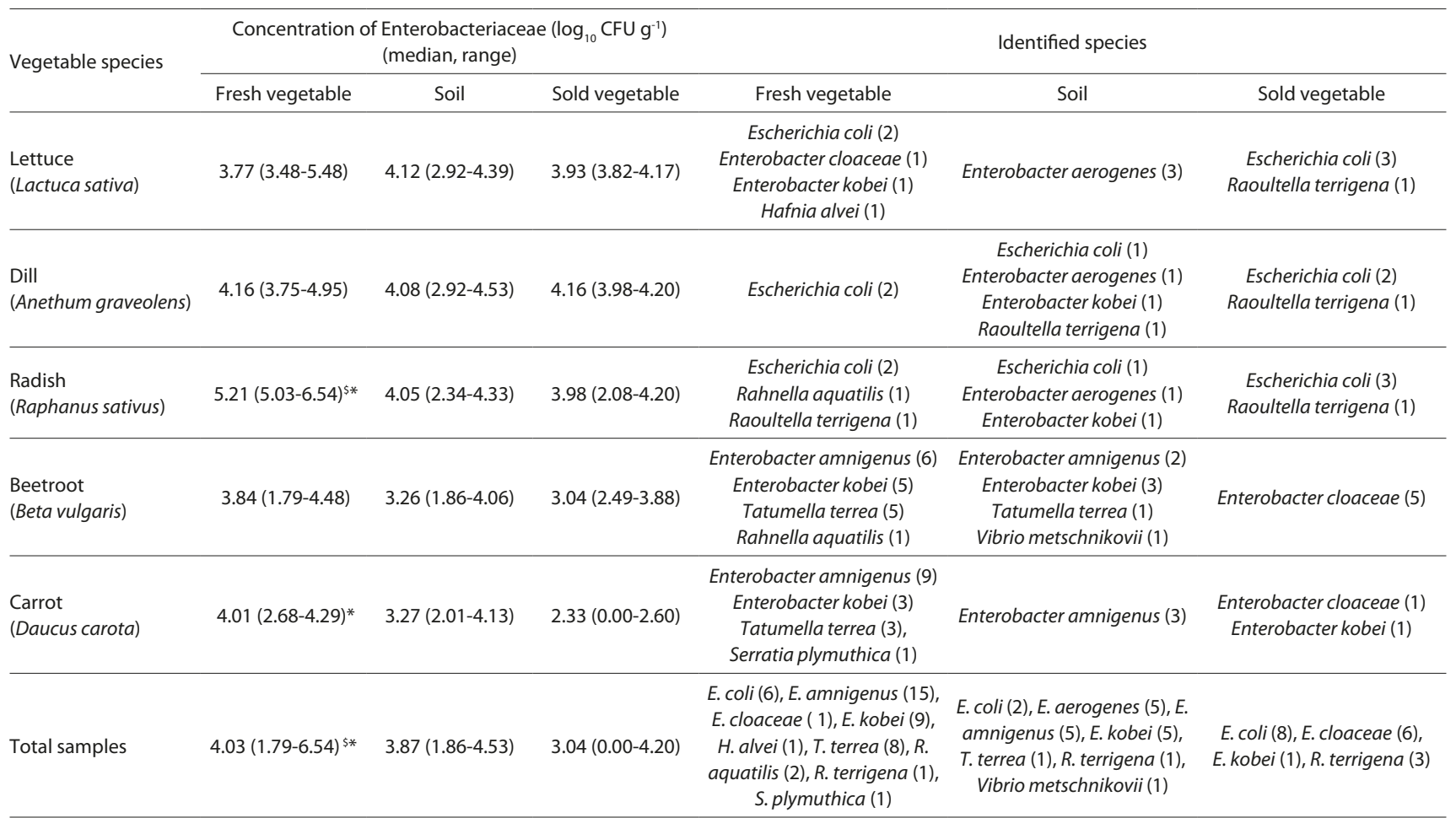

Number of samples analysed in each field equals 5 for lettuce, dill, and radish, 10 for sugar beet and carrot and 35 for total count. The numbers in parentheses after the names of identified species show the numbers of samples from which the species was isolated. 
The percent of samples containing E. coli was greatest for VR (22.9\%), smaller for FV (17.1\%) and smallest for SR (5.7\%). The prevalence of $E$. coli in SR was significantly lower compared to $\operatorname{VR}(\mathrm{P}=0.048)$, but no significant differences could be found between the prevalence of $E$. coli in FV vs. VR $(\mathrm{P}=0.546)$, as well as between FV and SR $(\mathrm{P}=0.138)$.

No significant correlation could be established between the concentrations of Enterobacteriaceae in fresh isolates and soil, which seems to indicate that a considerable part of these bacteria originated from sources other than soil.

Faecal coliform (FC) bacteria. The median concentrations of FC were $1.000 \log _{10} \mathrm{CFU} \mathrm{g}^{-1}$ in FV and SR and 0.00 in VR. Median values determined for particular kinds of vegetables ranged between $0.00-1.00 \log _{10} \mathrm{CFU} \mathrm{g}^{-1}$ (Tab. 3). The presence of FC was detected in 24 samples $(68.6 \%$ of the total examined samples) of FV, 29 samples (82.9\%) of SR and 12 samples (34.3\%) of VR, a total of 65 out of 105 samples examined (61.9\%). The prevalence of samples in which the concentration of FC reached, but never exceeded, the threshold limit value (TLV) of FC equal to $2.00 \log _{10} \mathrm{CFU} \mathrm{g}^{-1}$ (EC regulation 2005) was much smaller and accounted for 4 samples of FV $(11.4 \%$ of the total examined), 5 samples of SR (14.3\%) and 3 samples of VR (8.6\%), totally 12 samples (11.4\%).

The concentration of FC in total samples was significantly greater in FV and SR compared to $\mathrm{VR}(\mathrm{P}=0.008$ and $\mathrm{P}=0.0002$, respectively), but this relationship was not consistent and depended on the type of vegetable. The concentration of FC in FV and SR was significantly greater in root vegetables (radish, beetroots and carrot) than in leafy vegetables (lettuce and dill) $(\mathrm{P}=0.05$ and $\mathrm{P}=0.0018$, respectively), while conversely, in leafy vegetables the FC concentration in VR was distinctly greater than in root vegetables $(\mathrm{P}=0.00017)$. With respect to particular vegetables, the FC concentration in the lettuce VR was significantly greater compared to FV and SR (in both cases $\mathrm{P}=0.031)$, in the radish $\mathrm{SR}$ was significantly greater compared to $\mathrm{FV}$ and $\mathrm{VR}(\mathrm{P}=0.049$ and $\mathrm{P}=0.003$, respectively), while in beetroot and carrot $\mathrm{FV}$ and $\mathrm{SR}$ were significantly greater compared to VR (for beetroot $\mathrm{P}=0.0005$ and $\mathrm{P}=0.00013$, respectively, and for carrot $\mathrm{P}=0.0045$ and $\mathrm{P}=0.0056$, respectively).
When comparing the FC concentrations associated with particular vegetables, it was found that FV values of beetroots and carrot were significantly greater compared to lettuce $(\mathrm{P}=0.046$, and $\mathrm{P}=0.037$, respectively), and radish $(\mathrm{P}=0.046$ and $\mathrm{P}=0.037$, respectively). In contrast, $\mathrm{VR}$ value of lettuce was significantly greater compared to radish $(\mathrm{P}=0.0046)$, beetroots $(\mathrm{P}=0.0011)$ and carrot $(\mathrm{P}=0.006)$. Moreover, VR value of dill was significantly greater compared to beetroots $(\mathrm{P}=0.04)$.

Salmonella spp. All examined vegetable and soil samples tested were negative for the presence of Salmonella.

Clostridium perfringens (CP). The median concentrations of CP were $0.00 \log _{10} \mathrm{CFU} \mathrm{g^{-1 }}$ for all categories of samples. The bacterium was very rare in FV samples (occurred in only 2 out of 35 samples, $5.7 \%$ of the total) and totally absent in VR samples. Its presence was connected with soil (SR), being significantly greater compared to FV and VR $(\mathrm{P}=0.00041$, and $\mathrm{P}=0.000047$, respectively). C. perfringens was particularly common in soil samples from lettuce, dill and radish, occurring in $86.7 \%$ of SR samples associated with these vegetables, with median values equal to 2.0, 3.0 and 3.0, respectively (Tab. 3). In contrast, it was absent in SR samples from beetroots and rare in SR samples from carrot, where it was present in only $10 \%$ of samples. Totally, the bacterium was present in $40 \%$ of examined soil samples. Exceeding of the threshold limit value (TLV) of $4.00 \log _{10} \mathrm{CFU} \mathrm{g}^{-1}$ [25] was noted only in one soil sample each from lettuce and dill, and in 2 soil samples from radish. Summarizing, the exceeding of TLV was observed in only $11.4 \%$ of soil samples and $3.8 \%$ of the total examined samples. The occurrence of $C$. perfringens was significantly greater in soil associated with leafy vegetables, compared to root vegetables $(\mathrm{P}=0.0032)$.

\section{DISCUSSION}

The concentrations of aerobic mesophilic bacteria (AMB) in the samples of vegetables and soil associated with vegetables proved to be significantly greater for isolates recovered at

Table 3. Median concentrations and ranges (in parentheses) of potentially pathogenic bacteria used as sanitary indices in fresh vegetables, in soil from vegetable rhizosphere, and in vegetables sold at retail in the market

\begin{tabular}{|c|c|c|c|c|c|c|c|c|c|}
\hline \multirow{3}{*}{ Vegetable species } & \multicolumn{9}{|c|}{ Concentration of bacteria $\left(\log _{10}\right.$ CFU g $\left.{ }^{-1}\right)$ (median, range) } \\
\hline & \multicolumn{3}{|c|}{ Faecal coliforms } & \multicolumn{3}{|c|}{ Salmonella spp. } & \multicolumn{3}{|c|}{ Clostridium perfringens } \\
\hline & $\begin{array}{c}\text { Fresh } \\
\text { vegetable }\end{array}$ & Soil & $\begin{array}{c}\text { Sold } \\
\text { vegetable }\end{array}$ & $\begin{array}{c}\text { Fresh } \\
\text { vegetable }\end{array}$ & Soil & $\begin{array}{c}\text { Sold } \\
\text { vegetable }\end{array}$ & $\begin{array}{c}\text { Fresh } \\
\text { vegetable }\end{array}$ & Soil & $\begin{array}{c}\text { Sold } \\
\text { vegetable }\end{array}$ \\
\hline $\begin{array}{l}\text { Lettuce } \\
\text { (Lactuca sativa) }\end{array}$ & $\begin{array}{c}0.00 \\
(0.00-1.00)\end{array}$ & $\begin{array}{c}0.00 \\
(0.00-1.00)\end{array}$ & $\begin{array}{c}1.00^{\# \$} \\
(1.00-2.00)\end{array}$ & $\begin{array}{c}0.00 \\
(0.00-0.00)\end{array}$ & $\begin{array}{c}0.00 \\
(0.00-0.00)\end{array}$ & $\begin{array}{c}0.00 \\
(0.00-0.00)\end{array}$ & $\begin{array}{c}0.00 \\
(0.00-1.00)\end{array}$ & $\begin{array}{c}2.00^{\# *} \\
(0.00-4.00)\end{array}$ & $\begin{array}{c}0.0 \\
(0.00-0.00)\end{array}$ \\
\hline $\begin{array}{l}\text { Dill } \\
\text { (Anethum graveolens) }\end{array}$ & $\begin{array}{c}0.00 \\
(0.00-2.00)\end{array}$ & $\begin{array}{c}1.00 \\
(0.00-1.00)\end{array}$ & $\begin{array}{c}1.00 \\
(0.00-2.00)\end{array}$ & $\begin{array}{c}0.00 \\
(0.00-0.00)\end{array}$ & $\begin{array}{c}0.00 \\
(0.00-0.00)\end{array}$ & $\begin{array}{c}0.00 \\
(0.00-0.00)\end{array}$ & $\begin{array}{c}0.0 \\
(0.00-0.00)\end{array}$ & $\begin{array}{c}3.00^{\# *} \\
(0.00-4.00)\end{array}$ & $\begin{array}{c}0.0 \\
(0.00-0.00)\end{array}$ \\
\hline $\begin{array}{l}\text { Radish } \\
\text { (Raphanus sativus) }\end{array}$ & $\begin{array}{c}0.00 \\
(0.00-1.00)\end{array}$ & $\begin{array}{c}1.00^{\# *} \\
(1.00-1.00)\end{array}$ & $\begin{array}{c}0.00 \\
(0.00-0.00)\end{array}$ & $\begin{array}{c}0.00 \\
(0.00-0.00)\end{array}$ & $\begin{array}{c}0.00 \\
(0.00-0.00)\end{array}$ & $\begin{array}{c}0.00 \\
(0.00-0.00)\end{array}$ & $\begin{array}{c}0.0 \\
(0.00-0.00)\end{array}$ & $\begin{array}{c}3.00^{\# *} \\
(2.00-4.00)\end{array}$ & $\begin{array}{c}0.0 \\
(0.00-0.00)\end{array}$ \\
\hline $\begin{array}{l}\text { Beetroot } \\
\text { (Beta vulgaris) }\end{array}$ & $\begin{array}{c}1.0^{*} \\
(1.0-2.00)\end{array}$ & $\begin{array}{c}1.0^{*} \\
(1.0-2.00)\end{array}$ & $\begin{array}{c}0.00 \\
(0.00-1.00) \\
\end{array}$ & $\begin{array}{c}0.00 \\
(0.00-0.00)\end{array}$ & $\begin{array}{c}0.00 \\
(0.00-0.00) \\
\end{array}$ & $\begin{array}{c}0.00 \\
(0.00-0.00) \\
\end{array}$ & $\begin{array}{c}0.0 \\
(0.00-0.00) \\
\end{array}$ & $\begin{array}{c}0.0 \\
(0.00-0.00)\end{array}$ & $\begin{array}{c}0.0 \\
(0.00-0.00) \\
\end{array}$ \\
\hline $\begin{array}{l}\text { Carrot } \\
\text { (Daucus carota) }\end{array}$ & $\begin{array}{c}1.00^{*} \\
(0.00-2.00)\end{array}$ & $\begin{array}{c}1.00^{*} \\
(0.00-2.00)\end{array}$ & $\begin{array}{c}1.00 \\
(0.00-2.00)\end{array}$ & $\begin{array}{c}0.00 \\
(0.00-0.00)\end{array}$ & $\begin{array}{c}0.00 \\
(0.00-0.00)\end{array}$ & $\begin{array}{c}0.00 \\
(0.00-0.00)\end{array}$ & $\begin{array}{c}0.00 \\
(0.00-2.00)\end{array}$ & $\begin{array}{c}0.00 \\
(0.00-2.00)\end{array}$ & $\begin{array}{c}0.0 \\
(0.00-0.00) \\
\end{array}$ \\
\hline
\end{tabular}

Number of samples analysed in each field equals 5 for lettuce, dill, and radish, 10 for sugar beet and carrot and 35 for total count. The value ' 0.00 ' means that no bacteria were found in the sample; an auxiliary assumption that $1 \mathrm{CFU}$ was present in the sample has been done only to enable log-transforming. ${ }^{*}$ Number significantly greater compared to fresh vegetable. ${ }^{5}$ Number significantly greater compared to soil. *Number significantly greater compared to sold vegetable. 
$30^{\circ} \mathrm{C}$ compared to $37^{\circ} \mathrm{C}$, which suggests that the temperature of $30^{\circ} \mathrm{C}$ is optimal for further studies on bacteria occurring in this environment.

The AMB levels in 5 kinds of fresh vegetables (FV) taken immediately from soil were within the range of $3.54-6.32 \log _{10} \mathrm{CFU} \mathrm{g} \mathrm{g}^{-1}$, for isolates recovered at $30^{\circ} \mathrm{C}$. The AMB levels in the same kinds of vegetables sold at retail in the markets (VR), described often in the literature as unprocessed vegetables (UV) [4], were significantly lower, ranging from $0.00-5.55 \log _{10} \mathrm{CFU} \mathrm{g}$. The levels of $\mathrm{AMB}$ noted in the presented study for FV and VR were similar to those reported by Nguz et al. [6] (Zambia), Aycicek et al. [1] (Turkey), Oliveira et al. [7] and Soriano et al. [25] (Spain), Seow et al. [8] (Singapore), Cardamone et al. [4] (Italy), Johnston et al. [26, 27] (USA), Ryu et al. [3] (Korea), and by Wood et al. [28] (Canada), but lower compared to data reported by Abadias et al. [2] and Ercolani [29] (Spain), De Giusti et al. [11] (Italy), Viswanathan and Kaur [5] (India), and by Hagenmaier and Baker [30], Valentin-Ban et al. [31] and Korir et al. [32] (USA).

To the best of our knowledge, no studies on the concentration of bacteria in fresh or unprocessed vegetables have been performed in Poland until recently. Wójcik-Stopczyńska [33] examined the microbiological quality of minimally processed vegetable salads, finding the $\mathrm{AMB}$ concentrations within the range 4.0-7.0 $\log _{10}$ CFU g ${ }^{-1}$ and high concentrations of coliforms ranging from 3.0-5.0 $\log _{10} \mathrm{CFU} \mathrm{g}^{-1}$, but did not detect Salmonella, Proteus, Bacillus cereus and pathogenic staphylococci.

Until recently, no internationally recognized threshold limit values exist describing an allowable content of aerobic mesophilic bacteria in vegetables, so the levels obtained in the presented study could be only compared to the proposals of allowable AMB content published by various authors. Aycicek et al. [1] quoted the Hazard Analysis and Critical Control Points - Total Quality Management (HACCP-TQM) Technical Guidelines, describing the microbial quality for raw foods, according to which foods containing >4.0, 4.0-6.7, 6.7-7.7, and $<7.7 \log _{10}$ CFU g-1 of AMB are rated as 'good', 'average', 'poor' and 'spoiled food', respectively. According to this classification, all the mean values, and 31 out of 35 individual values $(88.6 \%)$ examined in the current study $\mathrm{FV}$ and VR samples (grown at $30^{\circ} \mathrm{C}$ ) could be classified as 'average', while the remaining 4 samples (2 FV and 2 VR samples, together $11.4 \%$ of the total) could be classified as 'good'. Exceeding of the German threshold value of 6.69 $\log _{10}$ CFU g-1 of AMB proposed by Lund (1993) and quoted by Nguz et al. [6] was never observed.

In contrast, as already mentioned above, 5 out of 35 individual FV samples grown at $30^{\circ} \mathrm{C}(14.3 \%$ of the total), but none of VR samples, exceeded the threshold limit value (TLV) of $6.0 \log _{10}$ CFU g-1 proposed by Gelosa (1998) and French norms (1993) quoted by De Giusti et al. [11]. None of the samples examined in this study exceeded the TLV level of $7.0 \log _{10} \mathrm{CFU} \mathrm{g}^{-1}$ proposed by the Public Health Laboratory Service and quoted by the same authors [11].

The concentrations of AMB in the samples of soil taken from the rhizosphere of the fresh vegetable specimens examined in the current study were within the range of 2.23-5.47 $\log _{10} \mathrm{CFU} \mathrm{g}^{-1}$ (for isolates recovered at $30^{\circ} \mathrm{C}$ ). They were significantly lower compared to $\mathrm{AMB}$ concentrations in fresh vegetables but, on the other hand, showed a highly significant correlation with them, which suggests that the majority of AMB recovered from fresh vegetables was of soil origin.

The levels of Enterobacteriaceae in fresh vegetables (FV) were within the range of $1.79-6.54 \log _{10}$ CFU g $\mathrm{g}^{-1}$. In the same kinds of vegetables sold at retail in the markets (VR), these levels were significantly lower, ranging from 0.00-4.20 $\log _{10}$ CFU g $g^{-1}$. The Enterobacteriaceae levels noted in the presented study for FV and VR (UV) were similar to those reported by Nguz et al. [6] (Zambia), Abadias et al. [2] and Oliveira et al. [7] (Spain), Seow et al. [8] (Singapore), and by Cardamone et al. [4] (Italy), slightly higher compared to data reported by Johnston et al. [26, 27] (USA), and by Ryu et al. [3] (Korea), but lower compared to data reported by Aycicek et al. [1] (Turkey) and by Viswanathan and Kaur [5] (India). The relatively abundant presence of the Enterobacteriaceae strains in the examined vegetables in the presented study was most probably not associated with a considerable risk for consumers, because the group of 11 species identified comprised only commensals of the human gastrointestinal tract, or free-living species which could be classified as opportunistic, but not obligatory pathogens.

The observation made in this study that leafy vegetables harbour greater concentrations of aerobic mesophilic bacteria and Enterobacteriaceae than root vegetables is in accordance with the results of Seow et al. [8] (Singapore) and Cardamone et al. [4] (Italy). This may be due to the fact that leafy vegetables have large surface areas for microbial attachment $[1,32]$.

The median concentrations of faecal coliform (FC) bacteria in the examined vegetables and soil ranged from $0.00-2.00 \log _{10}$ $\mathrm{CFU} \mathrm{g}$. The prevalence of samples with the FC concentration of $2.00 \log _{10}$ CFU g-1 was $11.4 \%$, approaching the prevalence of Escherichia coli equal to $15.2 \%$, determined by an alternative method consisting of isolation on eosin methylene blue (EMB) agar for Enterobacteriaceae, and identification of the grown colonies with metabolic micro-tests. Accordingly, it was assumed that the determined FC concentration of 2.00 $\log _{10}$ CFU g ${ }^{-1}$ corresponded to E. coli concentration of 2.00 $\log _{10}$ CFU g ${ }^{-1}$, proposed by the European Commission as the first grade of threshold limit value (TLV) for vegetables (EC Regulation 2005) [34]. This value corresponds with the TLV of the British Public Health Laboratory Service, according to which the food sample containing E. coli in the concentration equal to or greater than $2.00 \log _{10} \mathrm{CFU} \mathrm{g}^{-1}$ is classified as unsatisfactory [9]. Compared to results obtained by other authors, the presumptive prevalence of vegetable samples containing E. coli concentration reaching this TLV value $(11.4 \%)$ determined in the current study was greater compared to values reported by Abadias et al. [2] (Spain), Cardamone et al. [4] (Italy), Sagoo et al. [9] and McMahon and Wilson [35] (United Kingdom), Johannesen et al. [10] and Loncarevic et al. [36] (Norway), Valentin-Bon [31] and Mukherjee et al. [37, 38] (USA), and by Tango et al. [39] (Korea), and smaller compared to values reported by Nguz et al. [6] (Zambia), Aycicek et al. [1] (Turkey), de Giusti et al. [11] and Ercolani [29] (Italy), and by Viswanathan and Kaur [5] (India).

No Salmonella strains were detected in the examined samples of vegetables and soil.

In hitherto performed studies on microbiological quality of vegetables, the presence of Clostridium perfringens was determined relatively rarely. In the presented study, this bacterium was found to be common in soil associated with 
vegetables, with only rare evidence of penetration into the vegetables themselves. These results are in line with those obtained by other authors who have not detected $C$. perfringens in examined vegetables [6], or found only low levels of this bacterium not exceeding the proposed TLV [4]. Summarizing, it seems that $C$. perfringens does not pose a health risk for consumers of vegetables.

\section{CONCLUSIONS}

The results of this study generally indicate that the microbiological quality of Polish vegetables grown on conventional farms is satisfactory and safe for consumers. This thesis is supported by the moderate content of the aerobic mesophilic bacteria which, in most cases, could be assessed by existing proposals of hygienic norms as 'average' and not exceeding the threshold limit values. The other arguments speaking for the satisfactory microbiological quality of examined vegetables is lack of Salmonella, low content of Clostridium perfringens, and moderate contamination with Escherichia coli, which in $11.4 \%$ of the examined vegetables approximated but not exceeded the threshold limit value of $2.00 \log _{10} \mathrm{CFU} \mathrm{g}$. For a full estimation of health risk associated with the consumption of Polish vegetables, the authors plan the enhancement of future studies by tests for the presence of Escherichia coli O157:H7, Listeria monocytogenes, Campylobacter spp. and Yersinia spp., with respect also to organic farms.

Therefore, it can be stated that:

1. Vegetables and rhizosphere soil from conventional farms in Eastern Poland showed a low level of bacterial contamination.

2. No Salmonella was found in the examined vegetables and soil samples.

3. The percent of samples containing Escherichia coli was greatest for vegetables sold at retail in the markets, smaller for fresh vegetables and smallest for rhizosphere soil.

4. Contamination with Clostridium perfringens was very low in all examined samples of vegetables and soil.

\section{REFERENCES}

1. Aycicek H, Oguz U, Karci K. Determination of total aerobic and indicator bacteria on some raw eaten vegetables from wholesalers in Ankara, Turkey. Int J Hyg Environ Health. 2006; 209(2): 197-201.

2. Abadias M, Usall J, Anguera M, Solsona C, Viñas I. Microbiological quality of fresh, minimally-processed fruit and vegetables, and sprouts from retail establishments. Int J Food Microbiol. 2008; 123(1-2): 121129.

3. Ryu J H, Kim M, Kim E G, Beuchat L R, Kim H. Comparison of the microbiological quality of environmentally friendly and conventionally grown vegetables sold at retail markets in Korea. J Food Sci. 2014; 79(9): M1739-1744.

4. Cardamone C, Aleo A, Mammina C, Oliveri G, Di Noto A M. Assessment of the microbiological quality of fresh produce on sale in Sicily, Italy: preliminary results. J Biol Res. 2015; 22(3): 1-6.

5. Viswanathan P, Kaur R. Prevalence and growth of pathogens on salad vegetables, fruits and sprouts. Int J Hyg Environ Health. 2001; 203(3): 205-213.

6. Nguz K, Shindano J, Samapundo S, Huyghebaert A. Microbiological evaluation of fresh-cut organic vegetables produced in Zambia. Food Control. 2005; 15(5): 623-628.

7. Oliveira M, Usall J, Vinas I, Anguera M, Gatius F, Abadias M. Microbiological quality of fresh lettuce from organic and conventional production. Food Microbiol. 2010; 27: 679-684.
8. Seow J, Ágoston A, Phua L, Yuk H-G. Microbiological quality of fresh vegetables and fruits sold in Singapore. Food Control. 2012; 25(1): 39-44.

9. Sagoo S K, Little C L, Mitchell R T. The microbiological examination of ready-to-eat organic vegetables from retail establishments in the United Kingdom. Lett Appl Microbiol. 2001; 33(6): 434-439.

10. Johannessen G S, Loncarevic S, Kruse H. Bacteriological analysis of fresh produce in Norway. Int J Food Microbiol. 2002; 77(3): 199-204.

11. De Giusti M, Aurigemma C, Marinelli L, Tufi D, De Medici D, Di Pasquale $S$, el al. The evaluation of the microbial safety of fresh readyto-eat vegetables produced by different technologies in Italy. J Appl Microbiol. 2010; 109(3): 996-1006.

12. Olaimat A N, Holey R A. Factors influencing the microbial safety of fresh produce: A review. Food Microbiol. 2012; 32: 1-19.

13. Da Silva Felicio M T, Hald T, Liebana E, Allende A, Hugas M, NguyenThe C, Skoien Johannessen G, Niskanen T, Uyttendaele M, McLauchlin J. Risk ranking of pathogens in ready-to-eat unprocessed foods of nonanimal origin (FoNAO) in the EU: Initial evaluation using outbreak data (2007-2011). Int J Food Microbiol. 2015; 195: 9-19.

14. Erickson M C, Webb C C, Diaz-Perez J C, Phatak S C, Silvoy J J, Davey $\mathrm{L}$, et al. Infrequent internalization of Escherichia coli 0157:H7 into field-grown leafy greens. J Food Prot. 2010; 73: 500-506.

15. Lang N L, Smith S R. Influence of soil type, moisture content and biosolids application on the fate of Escherichia coli in agricultural soil under controlled laboratory conditions. J Appl Microbiol. 2007; 103: 2122-2131.

16. Nicholson F A, Groves S J, Chambers B J. Pathogen survival during livestock manure storage and following land application. Bioresour Technol. 2005; 96: 135-143.

17. Szejniuk B, Wasilewski P, Kubisz Ł, Szrajda P, Wroski G. Elimination of Salmonella senftenberg W ${ }_{775}$ bacteria in the cultivation of some agricultural crops (in Polish). Acta Sci Pol Agricultura. 2007; 6(4): 73-81.

18. Holley R A, Arrus K M, Ominski K H, Tenuta M, Blank G. Salmonella survival in manure-treated soils during simulated seasonal temperature exposure. J Environ Qual. 2006; 35: 1170-1180.

19. Franz E, Diepeningen van A D, Vos de O J, Bruggen van A H C. Effects of cattle feed-ing regimen and soil management type on the fate of Escherichia coli O157:H7 and Salmonella enterica serovar typhimurium in manure, manure-amended soil and lettuce. Appl Environ Microbiol. 2005; 71: 6165-6174.

20. Stroczyńska-Sikorska M, Prażmo Z, Kłapeć T. The survival of Salmonella spp. and E. coli in a variety of soil types, and sanitary and epidemiological considerations. Materials Scientific Conference of the Medical Geography "Health and the Environment", UMCS, Lublin 14-15.09.1993: 224-231 (in Polish).

21. Polish Standard PN-EN ISO 6222:2004. Water quality - Quantitative determination of microorganisms capable to grow. Determination the total number of colonies on nutrient agar culture (in Polish).

22. Polish Standards PN-77/C-04615/07. Water and sewage. Microbiological studies Determination of faecal coliform bacteria by tube fermentation technique (in Polish).

23. Polish Standards PN-Z-19000-1/2001. Soil quality-Assessment of the soil sanitary conditions-Detection of the Salmonella genus bacteria (in Polish).

24. Polish Standards PN-74/C-14615/2012. Water and sewage. Microbiological studies Determination of anaerobic sulfate reducing spore bacteria (Clostridium) farming method (in Polish).

25. Soriano J M, Rico H, Moltó J C, Mañes J. Assessment of the microbiological quality and wash treatments of lettuce served in University restaurants. Int J Food Microbiol. 2000; 58(1-2): 123-128.

26. Johnston L M, Jaykus L A, Moll D, Martinez M C, Anciso J, Mora B, et al. A field study of the microbiological quality of fresh produce. J Food Prot. 2005; 68(9): 1840-1847.

27. Johnston L M, Jaykus L A, Moll D, Anciso J, Mora B, Moe CL. A field study of the microbiological quality of fresh produce of domestic and Mexican origin. Int J Food Microbiol. 2006; 112(2): 83-95.

28. Wood J L, Chen J C, Friesen E, Delaquis P, Allen K J. Microbiological survey of locally grown lettuce sold at farmers'markets in Vancouver, British Columbia. J Food Prot. 2015; 78(1): 203-208.

29. Ercolani G L. Bacteriological quality assessment of fresh marketed lettuce and fennel. Appl Environ Microbiol. 1976; 31(6): 847-852.

30. Hagenmaier R D, Baker RA. A survey of the microbial population and ethanol content of bagged salad. J Food Prot. 1998; 61(3): 357-359.

31. Valentin-Bon I, Jacobson A, Monday S R, Feng PC. Microbiological quality of bagged cut spinach and lettuce mixes. Appl Environ Microbiol. 2008; 74(4): 1240-1242. 
32. Korir R C, Parveen S, Hashem F, Bowers J. Microbiological quality of fresh produce obtained from retail stores on the Eastern Shore of Maryland, United States of America. Food Microbiol. 2016; 56:29-34.

33. Wójcik-Stopczyńska B. Microbiological quality of minimally processed vegetable salads (in Polish). Rocz Panstw Zakl Hig. 2004; 55(2): 139-45.

34. European Commission. Commission Regulation (EC) No 2073/2005 of 15 November 2005 on microbiological criteria for foodstuffs. Official Journal of the European Union 22.12.2005, L 338/2 EN.

35. McMahon M A, Wilson IG. The occurrence of enteric pathogens and Aeromonas species in organic vegetables. Int J Food Microbiol. 2001; 70(1-2): 155-162.
36. Loncarevic S, Johannessen G S, Rørvik L M. Bacteriological quality of organically grown leaf lettuce in Norway. Lett Appl Microbiol. 2005; 41(2): 186-189.

37. Mukherjee A, Speh D, Dyck E, Diez-Gonzalez F. Preharvest evaluation of coliforms, Escherichia coli, Salmonella, and Escherichia coli O157:H7 in organic and conventional produce grown by Minnesota farmers. J Food Prot. 2004; 67(5): 894-900.

38. Mukherjee A, Speh D, Jones A T, Buesing K M, Diez-Gonzalez F. Longitudinal microbiological survey of fresh produce grown by farmers in the upper midwest. J Food Prot. 2006; 69(8): 1928-1936.

39. Tango C N, Choi N J, Chung M S, Oh D H. Bacteriological quality of vegetables from organic and conventional production in different areas of Korea. J Food Prot. 2014; 77(8): 1411-1417. 